\title{
Economic analysis of strategic control program $(5,8,11)$ for gastrointestinal nematodes in grazing beef cattle during the growing phase in Central Brazil
}

\author{
Análise econômica do programa de controle estratégico $(5,8,11)$ de \\ nematodas gastrointestinais em bovinos de corte em recria a pasto \\ no Brasil Central
}

\author{
Mário Henrique Conde ${ }^{1 *}$; Rafael Pereira Heckler²; Dyego Gonçalves Lino Borges ${ }^{3}$; \\ Valter Joost Van Onselen ${ }^{4}$; Ricardo Carneiro Brumatti"; \\ Fernando de Almeida Borges ${ }^{4}$
}

\begin{abstract}
This study aimed to analyze economically different control protocols for beef cattle gastrointestinal nematodes in Brazil. Field study data previously published was used to compare three groups: 1) nondosed; 2) current deworming program with two doses - May and November; and 3) alternative strategic control program with three doses - May, August, and November. An economic sensitivity analysis was performed based on beef carcass price (BCP) variation, thus creating three economic scenarios: 1) more probable (M) using the mean $\mathrm{BCP}$ in the studied region; 2) optimistic $(\mathrm{O})$ using the mean $\mathrm{BCP}$ plus standard deviation; and 3) pessimistic (P) using the mean BCP minus standard deviation. Stock valuation (SV), operational result (OP), and treatment differential (TD) were calculated for each scenario. Average BCP was US\$2.93 kg-1 carcass ( \pm US\$ $0.27 \mathrm{~kg}^{-1}$ carcass). The mean annual cost of deworming per animal was US\$ 5.43 and US\$ 7.97 for protocols with two and three doses, respectively. The cost of anthelmintic treatment represented $0.63 \%$ and $0.74 \%$ of operating results, both in M scenario. TD ranged from $9.5 \%$ to $27.6 \%$ for the assessed protocols. Regardless of the scenario, the protocol with three annual dosages presented the highest SV and OP, which economically justifies its implementation in strategic control of gastrointestinal nematodes in grazing beef cattle in Central Brazil. These results also demonstrate the relevance of strategic anthelmintic treatments in weaned stocker calves in tropical and humid subtropical areas.
\end{abstract}

Key words: Control. Cooperia spp. Economic. Haemonchus spp. Tropical.

\section{Resumo}

O objetivo deste estudo foi analisar diferentes protocolos de controle de nematodas gastrointestinais em bovinos de corte no Brasil. Dados de estudo de campo publicados anteriormente foram utilizados para comparar três grupos: 1) não dosificado; 2) o programa de desverminação utilizado atualmente com

1 Discente, Faculdade de Medicina Veterinária e Zootecnia, Universidade Federal de Mato Grosso do Sul. UFMS, Campo Grande, MS, Brasil. E-mail: marioh.vet@gmail.com

2 Dr., Instituto Federal Catarinense, IFC, Rio do Sul, SC, Brasil. E-mail: rafaelpheckler@gmail.com

3 Discente, Faculdade de Medicina Veterinária e Zootecnia, UFMS, Campo Grande, MS, Brasil. E-mail: dyegogborges@hotmail.com

4 Profs. Drs., Faculdade de Medicina Veterinária e Zootecnia, UFMS, Campo Grande, MS, Brasil. E-mail: valter.onselen@ufms. br; rbrumatti@gmail.com; fernando.borges@ufms.br

* Author for correspondence 
duas dosificações - maio e novembro; e 3) um programa de controle estratégico com três dosificações - maio, agosto e novembro. A análise de sensibilidade econômica foi realizada com base na variação do Preço da Carcaça Bovina (PCB), assim criando três cenários econômicos: mais provável $(\mathrm{M})$, utilizando o PCB médio na região do estudo; Otimista (O), usando o PCB mais o desvio padrão e pessimista (P), usando o PCB menos o desvio padrão. Para cada cenário, a valorização de estoque (VE), o resultado operacional (OP) e o diferencial de tratamento (DT) foram calculados. O PCB médio foi de US\$ $2.93 \mathrm{~kg}^{-1}$ de carcaça ( \pm US\$ $0.27 \mathrm{~kg}^{-1}$ de carcaça). O custo médio anual de desverminação por animal foi US\$ 5.43 e US\$ 7.97 no protocolo com duas e três doses, respectivamente, e o custo do anti-helmíntico representou $0.63 \%$ e $0.74 \%$ do resultado operacional, ambos no cenário $\mathrm{M}$. Os diferenciais de tratamento dos protocolos avaliados variaram de $9.5 \%$ a $27.6 \%$. Independentemente do cenário econômico simulado, o protocolo com três dosagens anuais apresentou a maior VE e OP entre os protocolos avaliados, justificando economicamente sua implementação para o controle estratégico de nematodas gastrointestinais de bovinos de corte criados em pastagem no Brasil Central e também demonstram a relevância de tratamentos anti-helmínticos estratégicos em bezerros desmamados em áreas subtropicais tropicais e úmidas.

Palavras-chave: Controle. Cooperia. Econômico. Haemonchus. Tropical.

\section{Introduction}

Brazilian beef cattle industry stands out on the world stage for having the second largest cattle herd, being the first largest producer, and the second largest exporter of beef and veal (USDA, 2017). With around 158 million hectares (ha) of pasture, wherein $36 \%$ native and $64 \%$ cultivated (IBGE, 2006), a remarkable characteristic of Brazilian beef cattle production systems is that, mostly, it can be considered as grass-fed based (FERRAZ; FELÍCIO, 2010). However, this resource is, mostly, exploited in an ineffective and unsustainable way. About $78 \%$ of the cultivated pastures has a stocking rate of 0.8 animal unit (AU*) per hectare (DIEESE, 2011), which is considered low since the animal support capacity of forage species less demanding in soil quality varies on average from 1 to $1.5 \mathrm{AU} \mathrm{ha}^{-1}$ year ${ }^{1}$ (VALLE et al., 2010).

The Brazilian livestock production almost exclusively grass-fed associated with tropical characteristics, hot and humid summers and cold and dry winters, provides conditions for an all-yearround occurrence of gastrointestinal nematodes (GINs) in bovines (HECKLER et al., 2016), thereby negatively affecting animal reproduction and production performances, even that of their offspring (LOYACANO et al., 2002). These same epidemiological characteristics can be observed in other tropical humid regions, such as in northern Argentina (SUAREZ et al., 2018) and Tanzania (KEYYU et al., 2009), where Cooperia spp. and Haemonchus spp. are predominant with increasing fecal egg counts (FEC) in mid-winter (dry period).

Anthelmintics contributes to increase production performance of cattle, mainly in growing animals, with weight gains ranging from 11.85 to $49 \mathrm{~kg}$ per animal, when compared to non-dosed animals (KEYYU et al., 2009; HÖGLUND et al., 2013; BORGES et al., 2013; SUAREZ et al., 2018). Besides animal production performance, the entire livestock production chain could be affected by GINs. Annual direct losses in Brazil are estimated in US\$ 7.1 billion, which represents $51 \%$ of annual losses by parasites (GRISI et al., 2014). In addition, the use of anthelmintics with low efficacy, due to GIN-resistant populations, can lead to losses in cattle production (BORGES et al., 2013; CANDY et al., 2018).

Most Brazilian cattle ranchers (about $80 \%$ ) use anthelmintic treatments only to merge this management with other activities, mainly compulsory vaccination against foot-andmouth disease (FMD) in May and November, disregarding GIN epidemiology (BIANCHIN, 1991; SOUTELLO et al., 2007), which, in the conditions of central-western Brazil, during the 
dry period of the year (May to September), occurs a reduction of environmental contamination, thus being recommended anthelmintic treatments in this period (BIANCHIN, 1991).

To this end, an alternative strategic control against GINs of beef cattle was proposed in Midwest Brazil (HECKLER et al., 2016). This new proposal aims to merge fixed cattle handling practices and GIN epidemiology described by Bianchin et al. (1996). That said, treatments should be performed in May, with FMD vaccination since parasitic loads in animals increase at the beginning of the dry period; in August, due to a nutritional and immunological deficit by reductions in forage quality during the dry season; and in November, seeking to reduce environmental contamination for the next (rainy) season hence coming years, in addition to merge with the second FMD vaccination (HECKLER et al., 2016).

Other studies in tropical and subtropical regions have been conducted, such as a program of four strategic treatments per year in Tanzania (KEYYU et al., 2009), and a combination of two anthelmintics of different classes at two different times during the summer grazing in the Gulf Coast, United States (WALKER et al., 2013). Although benefits of these programs have been discussed, financial shortfalls in the economy of producing countries have not been reported frequently, as well as studies on the interaction among parasite control, productivity, and economic aspects. Therefore, this study aimed to perform an economic analysis on a GIN strategic control for beef cattle and compared it to nontreated herds and to conventional treatment protocol of weaned animals raised extensively under tropical climate conditions.

\section{Material and Methods}

Firstly, we performed a simulated financial evaluation of the six deworming protocols evaluated by Heckler et al. (2016), based on the economic scenario from January 2015 to December 2017.
The assessed variables were: deworming cost (DC), stock valuation (SV), operating result (OP), and treatment differential, expressed in dollars (US\$).

DC was calculated according to the following formula: $\mathrm{DC}=$ Cost of Anthelmintic + Labor Cost; wherein: Labor Cost $(\mathrm{LC})=$ (value of anthelmintic product/ product volume) $\mathrm{x}$ (average weight of animals/ dose). The value of the products was set to US\$ 77.93 for $3.5 \%$ doramectin (TreoAce ${ }^{\circledR}$ ), US\$ 47.96 for $1 \%$ moxidectin (Cydectin ${ }^{\circledR}$ ), and US\$ 6.30 for $18.8 \%$ levamisole (Ripercol $\AA$ ). The administered dose was calculated using the individual weight of animals, following the manufacturer's recommendation of $0.7 \mathrm{mg} \mathrm{kg}^{-1}$ for $3.5 \%$ doramectin, $0.2 \mathrm{mg} \mathrm{kg}^{-1}$ for $1 \%$ moxidectin, and $4.7 \mathrm{mg} \mathrm{kg}^{-1}$ for $18.8 \%$ levamisole. The labor cost (LC) was US\$ 34.17 , regarding a working day for a team of four rural workers, who received monthly a rural minimum wage at the time and place of study.

Stock valuation (SV) was estimated by the following formula: $\mathrm{SV}=$ mean final weight gain $\mathrm{x}$ beef carcass prices $(\mathrm{BCP}) \mathrm{x}$ carcass yield.

Carcass yield was estimated at 53\%, according to the national average for Zebu breed (ABIEC, 2017). For $\mathrm{BCP}$, we used the values traded in the region reported by Heckler et al. (2016), according to the Cepea-Esalq/USP database from January 2015 to December 2017, expressed in US\$ per kg of carcass (US\$ kg-1 carc.) (Figure 1).

Operational result (OP) was obtained by the following formula: $\mathrm{OP}=\mathrm{SV}-\mathrm{DC}$, being calculated for all the evaluated groups and expressed in dollars (US\$). Treatment differential (TD) was estimated as the difference between the operating result of evaluated groups and expressed in dollars (US\$). The TD of each group was calculated in relation to T1 (TD1) and T2 (TD2) groups.

A sensitivity analysis of BCP for the period between January 2015 and December 2017 was performed, determining the mean, maximum, minimum and standard deviation. Based on this analysis and on the animal production performance 
reported by Heckler et al. (2016), a MOP analysis (GITMAN, 2001) was performed for the three treatment protocols: T1 - non-dose, T2 conventional protocol with two annual doses in the months of May and November (3.5\% doramectin), and T3 - three annual doses in the months of May (3.5\% doramectin), August ( $1 \%$ moxidectin), and November $(3.5 \%$ doramectin). Three economic scenarios were created: a more probable (M), using the mean $\mathrm{BCP}$ of the studied region; an optimistic $(\mathrm{O})$, using the BCP plus standard deviation; and a pessimistic $(\mathrm{P})$, using the $\mathrm{BCP}$ minus standard deviation. For each scenario, SV, OP, TD1, and TD2 were calculated. Subsequently, for scenario M, the behavior of these variables was evaluated for different herd sizes.

Figure 1. Economic scenarios and annual oscillation of beef carcass prices (US $\left.\$ \mathrm{~kg}^{-1}\right)$ in the Brazilian market, between 2015 and 2017, according to the Cepea-Esalq/USP.

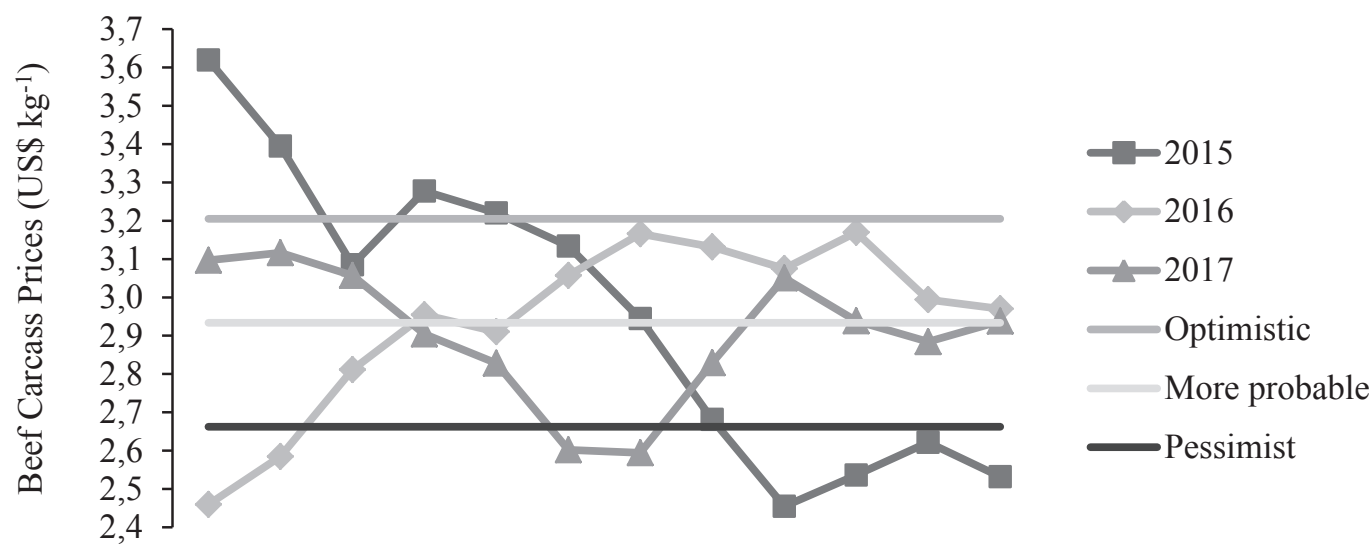

Jan Feb Mar Apr May Jun Jul Aug Sep Oct Nov Dec

The economic losses in cattle due to GINs were estimated by the reductions in SV, since the nondosed group showed neither mortality nor weight loss only in two out of the 26 monthly weight gain assessments, according to data obtained by Heckler et al. (2016).

\section{Results and Discussion}

Even though cost-benefit analysis is more suitable for economic evaluation of GINs in cattle, the fraction that could be recovered through the use of control strategy was difficult to determine (VAN DER VOORT et al., 2013). In this study, such analysis was enabled by the use of field data (HECKLER et al., 2016) of six treatment strategies: T1: non-dosed; T2: May and November with doramectin at 3.5\%; T3: May (3.5\% doramectin), July (18.8\% levamisole), and September (3.5\% doramectin); T4: May (3.5\% doramectin), July (1\% moxidectin), and September (3.5\% doramectin); T5: May (3.5\% doramectin), August (18.8\% levamisole), and November (3.5\% doramectin); T6: May (3.5\% doramectin), August (1\% moxidectin), and November (3.5\% doramectin).

Table 1 shows the financial evaluation of these treatment protocols. Animal production performance (weight gain) in T6 was statistically equal to those of $\mathrm{T} 3, \mathrm{~T} 4$, and $\mathrm{T} 5$ but the only one superior to $\mathrm{T} 2$ and T1 (HECKLER et al., 2016). In addition, two of the three T6 doses could be reconciled with FMD vaccination management, making it more applicable; thus, the other economic analyses were applied only for T1, T2, and T6.

A historical series analysis of BCP in 2015, 2016, and 2017 showed annual oscillations of $60.83 \%$, $33.62 \%$, and $10.52 \%$, respectively (Figure 1 ). When 
a five-year period was considered (2013 to 2017), had to be performed; thus, the risk of adopting BCP average increased by $47.8 \%$ (CEPEA, 2018). deworming protocols in different scenarios could In view of such instability, a sensitivity analysis be evaluated.

Table 1. Economic analysis of a financial simulation of production performance per animal for six strategic control treatments against gastrointestinal nematodes in cattle evaluated by Heckler et al. (2016).

\begin{tabular}{cccccccc}
\hline Treatment & MWG (Kg) & SV (US\$) & CA (US\$) & LC (US\$) & DC (US\$) & OP(US\$) & TD1 (US\$) \\
\hline T1 & 106.77 & 166.00 & - & 6.41 & 6.41 & 159.59 & - \\
\hline T2 & 120.80 & 187.81 & 1.16 & 4.27 & 5.43 & 182.38 & 22.79 \\
\hline T3 & 131.44 & 204.36 & 1.26 & 6.41 & 7.67 & 196.69 & 37.10 \\
\hline T4 & 131.17 & 203.93 & 1.49 & 6.41 & 7.89 & 196.04 & 36.45 \\
\hline T5 & 134.39 & 208.94 & 1.31 & 6.41 & 7.72 & 201.22 & 41.63 \\
\hline T6 & 140.88 & 219.03 & 1.57 & 6.41 & 7.97 & 211.06 & 51.46 \\
\hline
\end{tabular}

MWG: Mean Weight Gain, SV: Stock Valuation, CA: Cost of Anthelmintic, LC: Labor Cost, DC: Deworming Cost, OP: Operation result, TD1: Treatment Differential in relation to T1. T1: non-dosed, T2: May and November with doramectin at 3.5\%, T3: May (3.5\% doramectin), July (18.8\% levamisole), and September (3.5\% doramectin), T4: May (3.5\% doramectin), July (1\% moxidectin), and September (3.5\% doramectin), T5: May (3.5\% doramectin), August (18.8\% levamisole), and November (3.5\% doramectin), T6: May (3.5\% doramectin), August (1\% moxidectin), and November (3.5\% doramectin).

According to the sensitivity analysis, between January 2015 and December 2017, minimum, average, and maximum BCP values were US\$2.32, US\$ 2.93, and US\$ $3.71 \mathrm{~kg}^{-1}$, respectively. Mean value plus standard deviation was US\$ $3.20 \mathrm{~kg}^{-1}$ for scenario $\mathrm{O}$, and mean value minus standard deviation was US\$2.66 $\mathrm{kg}^{-1}$ for scenario P. Table 2 presents the simulations of economic scenarios (MOP analysis).

Table 2. Mean deworming cost (DC), stock valuation (SV), operating result (OP), and treatment differential (TD) per animal, expressed in dollars (US\$), for each treatment and the three simulated economic scenarios (more probable, optimistic, and pessimistic).

\begin{tabular}{|c|c|c|c|c|c|c|c|c|}
\hline \multirow{2}{*}{ Economic scenario } & \multirow{2}{*}{ Treatment } & \multirow{2}{*}{ SV (US\$) } & \multirow{2}{*}{ DC (US\$) } & \multirow{2}{*}{ OP(US\$) } & \multicolumn{2}{|c|}{ TD1 } & \multicolumn{2}{|c|}{ TD2 } \\
\hline & & & & & US\$ & $\%$ & US\$ & $\%$ \\
\hline \multirow{3}{*}{ Pessimistic } & $\mathrm{T} 1$ & 150.64 & 0.00 & 150.64 & - & - & - & - \\
\hline & $\mathrm{T} 2$ & 170.44 & 5.43 & 165.01 & 14.37 & $9.5 \%$ & - & - \\
\hline & T6 & 198.77 & 7.97 & 190.80 & 40.15 & $26.7 \%$ & 25.78 & $15.6 \%$ \\
\hline \multirow{3}{*}{ More probable } & $\mathrm{T} 1$ & 166.00 & 0.00 & 166.00 & - & - & - & - \\
\hline & $\mathrm{T} 2$ & 187.81 & 5.43 & 182.38 & 16.39 & $9.9 \%$ & - & - \\
\hline & T6 & 219.03 & 7.97 & 211.06 & 45.06 & $27.1 \%$ & 28.67 & $15.7 \%$ \\
\hline \multirow{3}{*}{ Optimistic } & $\mathrm{T} 1$ & 181.35 & 0.00 & 181.35 & - & - & - & - \\
\hline & $\mathrm{T} 2$ & 205.19 & 5.43 & 199.76 & 18.41 & $10.1 \%$ & - & - \\
\hline & T6 & 239.29 & 7.97 & 231.32 & 49.96 & $27.6 \%$ & 31.56 & $15.8 \%$ \\
\hline
\end{tabular}

Economic scenario: More Probable, using the average BCP in the studied region; Optimistic, using the BCP plus standard deviation; and Pessimistic, using the BCP minus standard deviation. T1 - non-dosed, T2 - conventional protocol with two annual doses of 3.5\% doramectin in the months of May and November, and T3 - three annual doses in the months of May (3.5\% doramectin), August ( $1 \%$ moxidectin), and November (3.5\% doramectin). TD1: treatment differential in relation to T1. TD2: treatment differential in relation to $\mathrm{T} 2$. 
In this study, fixed and variable production costs were inserted into DC. As a fixed cost, LC for deworming was considered, regardless of any other activity (e.g., FMD vaccination). LC was simulated since treatment protocols were tested under experimental conditions in the ranch intended for research purposes; therefore, the ranch costs would not represent reality. As a variable cost, only anthelmintics purchase cost was considered.

The mean deworming cost (DC) per animal in T2 was US\$ 2.67 in May and US\$ 2.76 in November, with a total cost of US\$ 5.23 animal $^{-1}$ year ${ }^{-1}$. For T6, it was US\$ 2.67 in May, US\$ 2.50 in August, and US\$ 2.80 in November, totaling US\$ 7.97 animal $^{-1}$ year ${ }^{-1}$. LC was US\$ 4.27 animal $^{-1}$ year $^{-1}$ and US $\$ 6.41$ animal $^{-1}$ year $^{-1}$ for T2 and T6, respectively. When DCs were converted into $\mathrm{kg}$ of carcass in scenario $\mathrm{M}$, the following conclusion was made: if compared to $\mathrm{T} 1$, each $1 \mathrm{~kg}$ invested in animal deworming provided economic gains equivalent to $3.13 \mathrm{~kg}$ and $5.65 \mathrm{~kg}$ of carcass in T2 and T6, respectively.

Anthelmintic cost in scenario $M$ represented $0.63 \%$ of OP in T2 and $0.74 \%$ in T6. Yet, in scenario
$\mathrm{P}$, this cost represented $0.70 \%$ and $0.82 \%$ of OP in $\mathrm{T} 2$ and $\mathrm{T} 6$ respectively. Regardless of the scenario, these results show that deworming costs do not exceed $1.0 \%$ of OP.

Comparing OP with anthelmintic cost, we could note that each US\$ 1.00 spent on deworming resulted in a return of US\$ 157.2 and US\$ 134.4 using two and three annual doses, respectively. The protocol of three annual dosages presented a lower rate of return in relation to that with two annual dosages. Despite this difference, the protocol with two doses could also be adopted since it showed higher profitability, given its higher OP results in all the simulated scenarios.

DC was calculated for a 16-animal herd, as used by Heckler et al. (2016), although the operational capacity of the team of workers considered in the analysis is greater. Thus, DC can decrease with an increasing number of animals handled per day (Figure 2). The reduction of DC was more intense up to 200 animals handled per day, above that, it was smaller.

Figure 2. Simulation of economic efficiency in different herd sizes (T1, T2, and T6 groups).

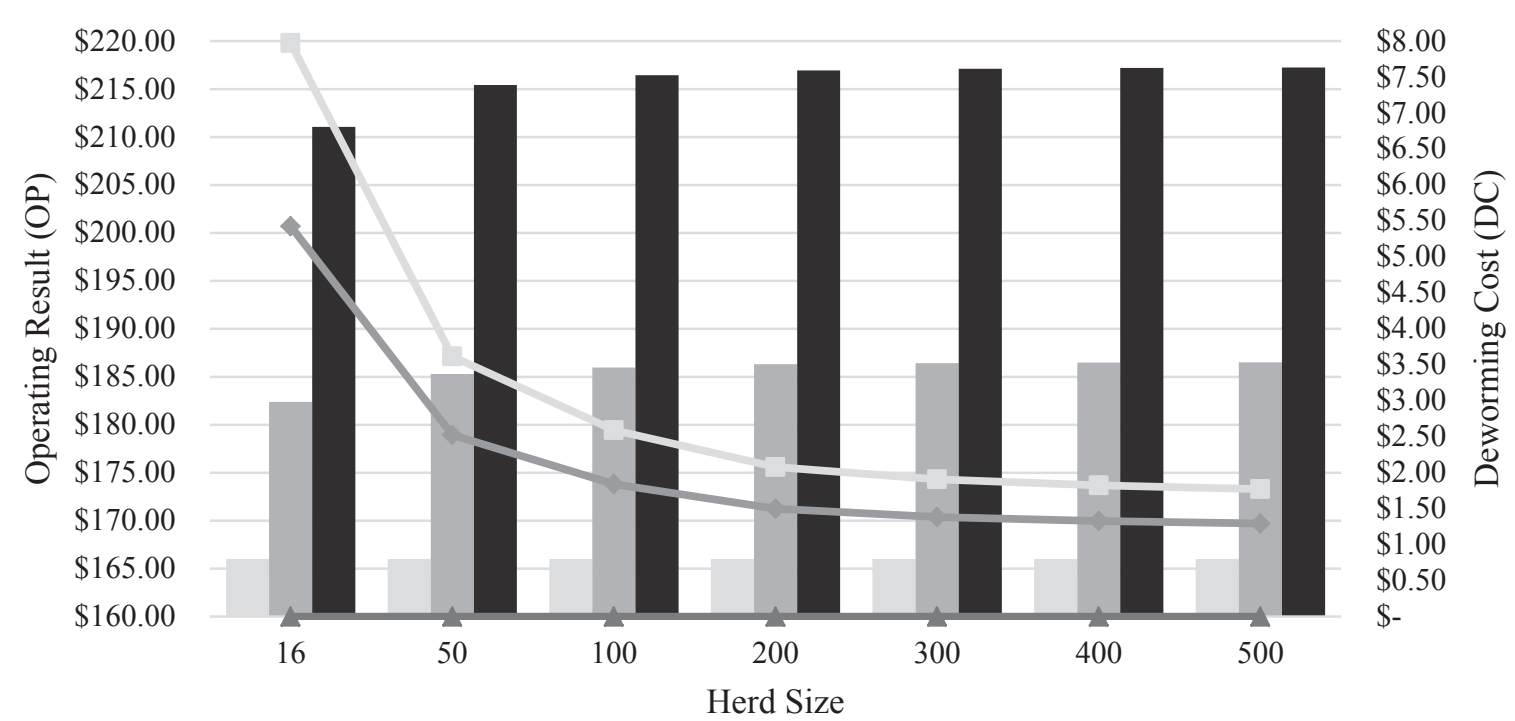

OP T1 OP T2 OP T6

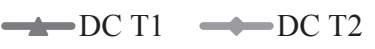

DC T6

T1 - non-dosed, T2 - conventional protocol with two annual doses (in May and November) using 3.5\% doramectin, and T3 - three annual doses in the months of May (3.5\% doramectin), August ( $1 \%$ moxidectin), and November (3.5\% doramectin). 
The gain from the use of the deworming protocols was economically simulated by the stock valuation variable. Since the animal category, at the end of the study by Heckler et al. (2016), did not fit into any of the indicators (bull and calf) in the CepeaEsalq/USP database, whose prices and indicators are extremely relevant for Brazilian agribusiness. Therefore, this category was considered as a stock for farms and the performance of protocols was in accordance with the valuation of this stock, that is, how much value will be added to these animals in future commercialization. Table 2 presents the simulation of this stock valuation.

Even non-dewormed animals showed weight gains, hence stock was valued. However, this valorization was much lower (Table 1) than that of treated animals ( 2 or 3 doses year ${ }^{-1}$ ). This might have occurred due to higher protein, energetic, and mineral demands of animals (POPPI et al., 1990; GÁRATE-GALLARDO et al., 2015) in an attempt to maintain homeostasis and productive performance, due to GINs parasitism. Thereby, nondosed animals in scenario $M$ ceased to be valued at US\$ 53.03 animal $^{-1}$ if compared to those dosed three times a year, and at US\$ 21.82 animal $^{-1}$ compared to those dosed twice a year. In scenario $\mathrm{O}$, non-dosed animals ceased to be valued at US\$23.83 and at US $\$ 57.94$ animal $^{-1}$ compared to those dosed two and three times a year, respectively. In the long term, the losses of non-dosed animals may be even greater, since non-dosed animals or those treated twice a year would need to remain longer in pastures to reach the same weight as those dosed three times a year, thereby reducing ranch profitability.

When using an average annual stocking rate of 1.05 AU ha $\mathrm{ha}^{-1}$, as in Heckler et al. (2016), a productivity increase of US\$ $57.34 \mathrm{ha}^{-1}$ year $^{-1}$ is expected in scenario $M$, only by adding a single anthelmintic treatment in August, compared to the practice adopted by ranchers to control GINs (2 treatments year-1). This represents an increase of $31.4 \%$ in productivity per area. Not only was it added an additional dosage, but a specific time was established (peak dry season), aiming to increase animal performance and area productivity, also seeking to reduce environmental contamination by non-parasitic stages of GINs.

Differences in the evaluated economic variables might be even more significant if tested in larger herds since LC would be diluted (Figure 2). However, for MOP analysis of T1, no DC was considered to represent the ranches adopted no anthelmintic treatment protocol. Thus, weight gain under this situation could be greater since animals are not handled, and hence the differences are reduced.

Nevertheless, the protocol using three annual doses was numerically superior for the three evaluated variables (stock valorization, operational result, and treatment differential), regardless of the simulated economic scenario, proving the economic superiority of an alternative strategic control program for GINs in grazing beef cattle during the growing phase in Central Brazil, compared to the traditional strategic control, and also the economic impact of GINs in beef cattle.

\section{Conclusion}

Compared to the other protocols evaluated in this study, the strategic control program of gastrointestinal nematodes with three annual doses (May, August, and November), known as 5-8-11, improved the production and economic performances of grazing beef cattle during the growing phase in Central Brazil, regardless of the simulated economic scenario. In addition, the study also underscored the relevance of strategic anthelmintic treatments for weaned calves in tropical and humid subtropical areas.

\section{References}

ASSOCIAÇÃO BRASILEIRA DAS INDÚSTRIAS EXPORTADORAS DE CARNE - ABIEC. Perfil da pecuária no Brasil - Relatório Anual. São Paulo: [s.n.], 
2017. Disponível em: http://abiec.siteoficial.ws/images/ upload/sumario-pt-010217.pdf. Acesso em: 25 set. 2018.

BIANCHIN, I. Epidemiologia e controle de helmintos gastrintestinais em bezerros a partir da desmama, em pastagem melhorada, em clima tropical do Brasil. 1991. Tese (Doutorado em Ciências em Medicina Veterinária) - Universidade Federal Rural do Rio de Janeiro, Seropédica.

BIANCHIN, I.; HONER, M. R.; NUNES, S. G.; NASCIMENTO, Y. A.; CURVO, J. B. E.; COSTA, F. P. Epidemiologia dos nematódeos gastrintestinais em bovinos de corte nos cerrados e o controle estratégico no Brasil. Campo Grande: EMBRAPA Gado de Corte, 1996. 120 p. (Circular técnica, 24).

BORGES, F. A.; ALMEIDA, G. D.; HECKLER, R. P.; LEMES, R. T.; ONIZUKA, M. K. V.; BORGES, D. G. L. Anthelmintic resistance impact on beef cattle productivity: effect on weight gain of weaned calves. Tropical Animal Health and Production, Edinburgh, v. 45 , n. 3 , p. $723-727,2013$. DOI: $10.1007 / \mathrm{s} 11250-012-$ $0280-4$

CANDY, P. M.; WAGHORN, T. S.; MILLER, C. M.; GANESH, S.; LEATHWICK, D. M. The effect on liveweight gain of using anthelmintics with incomplete efficacy against resistant Cooperia oncophora in cattle. Veterinary Parasitology, Amsterdam, v. 251, p. 56-62, 2018. DOI: $10.1016 /$ j.vetpar.2017.12.023

CENTRO DE ESTUDOS AVANÇADOS EM ECONOMIA APLICADA - CEPEA. Indicador do boi gordo. Piracicaba: [s.n.], 2018. Disponível em: https:// www.cepea.esalq.usp.br/br/indicador/boi-gordo.aspx. Acesso em: 25 set. 2018.

\section{DEPARTAMENTO INTERSINDICAL DE} ESTATÍSTICA E ESTUDOS SOCIOECONÔMICOS - DIEESE. Estatísticas do meio rural 2010-2011. 4. ed. São Paulo: Ministério do Desenvolvimento Agrário, 2011. $292 \mathrm{p}$.

FERRAZ, J. B. S.; FELÍCIO, P. E. D. Production systems $\square$ an example from Brazil. Meat Science, Barking, v. 84, n. 2, p. 238-243, 2010.

GÁRATE-GALLARDO， L.; TORRES-ACOSTA，J. F. J.; AGUILAR-CABALLERO, A. J.; SANDOVALCASTRO, C. A.; CAMARA-SARMIENTO, R.; CANUL-KU, H. L. Comparing different maize supplementation strategies to improve resilience and resistance against gastrointestinal nematode infections in browsing goats. Parasite, Paris, v. 22, n. 19, 2015. DOI: 10.1051/parasite/2015019

GITMAN, L. J. Princípios da administração financeira: essencial. 2. ed. Porto Alegre: Bookman, 2001. 610 p.
GRISI, L.; LEITE, R. C.; MARTINS, J. R. S.; BARROS, A. T. M.; ANDREOTTI, R.; CANÇADO, P. H. D.; LEÓN, A. A. P.; PEREIRA, J. B.; VILLELA, H. S. Reassessment of the potential economic impact of cattle parasites in Brazil. Revista Brasileira de Parasitologia Veterinária, Jaboticabal, v. 23, n. 2, p. 150-156, 2014. DOI: $10.1590 / \mathrm{S} 1984-29612014042$

HECKLER, R. P.; BORGES, D. G. L.; VIEIRA, M. C.; CONDE, M. H.; GREEN, M.; AMORIM, M. L.; ECHEVERRIA, J. T.; OLIVEIRA, T. L.; MORO, E.; VAN ONSELEN, V. J.; BORGES, F. A. New approach for the strategic control of gastrointestinal nematodes in grazed beef cattle during the growing phase in central Brazil. Veterinary Parasitology, Amsterdam, v. 221, p. 123-129, 2016. DOI: 10.1016/j.vetpar.2016.03.010

HÖGLUND, J.; DAHLSTRÖM, F.; SOLLENBERG, S.; HESSLE, A. Weight gain-based targeted selective treatments (TST) of gastrointestinal nematodes in first-season grazing cattle. Veterinary Parasitology, Amsterdam, v. 196 , n. $3-4$, p. $358-365$, 2013. DOI: 10.1016/j.vetpar.2013.03.028

INSTITUTO BRASILEIRO DE GEOGRAFIA E ESTATÍSTICA - IBGE. Censo agropecuário. Rio de Janeiro: [s.n.], 2006. Disponível em: https:// seriesestatisticas.ibge.gov.br/series.aspx?no=1\&op= $0 \&$ vcodigo $=$ AGRO03\& $\mathrm{t}=$ utilizacao-terras - ha. $\quad$ Acesso em: 25 set. 2018.

KEYYU, J.; KYVSGAARD, N.; MONRAD, J.; KASSUKU, A. Effectiveness of strategic anthelmintic treatments in the control of gastrointestinal nematodes and Fasciola gigantica in cattle in Iringa region, Tanzania. Tropical Animal Health and Production, Edinburgh, v. 41, n. 1, p. 25-33, 2009. DOI: $10.1007 /$ s11250-008-9150-5

LOYACANO, A. F.; WILLIAMS, J. C.; GURIE, J.; DEROSA, A. A. Effect of gastrointestinal nematode and liver fluke infections on weight gain and reproductive performance of beef heifers. Veterinary Parasitology, Amsterdam, v. 107, n. 3, p. 227-234, 2002. DOI: 10.1016/ S0304-4017(02)00130-9

POPPI, D. P.; SYKES, A. R.; DYNES, R. A. The effect of endoparasitism on host nutrition the implications for nutrient manipulation. Proceeding of the New Zealand Society of Animal Production, New Zealand, v. 50, p. 237-243, 1990.

SOUTELLO, R. G. V.; SENO, M. C. Z.; AMARANTE, A. F. T. Anthelmintic resistance in cattle nematodes in northwestern São Paulo State Brazil. Veterinary Parasitology, Amsterdam, v. 148, n. 3-4, p. 360-364, 2007. DOI: $10.1016 /$ j.vetpar.2007.06.023 
SUAREZ, V. H.; MARTÍNEZ, G. M.; MICHELOUD, J. F.; VIÑABAL, A. E. Epidemiology and effect of gastrointestinal nematodes on beef cattle from tropical Argentina. Tropical Animal Health and Production, Edinburgh, v. 50, n. 4, p. 801-806, 2018. DOI: $10.1007 /$ s11250-017-1498-y

UNITED STATES DEPARTMENT AGRICULTURE USDA. Livestock and poultry: world markets and trade. Washington: [s.n.], 2017. Available at: https://apps.fas. usda.gov/psdonline/app/index.html\#/app/ downloads. Accessed at: 25 set. 2018.

VALLE, C. B.; MACEDO, M. C. M.; EUCLIDES, V. P. B.; JANK, L.; RESENDE, R. M. S. Gênero Brachiaria. In: FONSECA, D. M.; MARTUSCELLO, J. A. (Ed.). Plantas forrageiras. Viçosa, MG: Editora UFV, 2010. p. 30-77.
VAN DER VOORT, M.; CHARLIER, J.; LAUWERS, L.; VERCRUYSSE, J.; VAN HUYLENBROECK, G.; VAN MEENSEL, J. Conceptual framework for analyzing farm-specific economic effects of helminth infections in ruminants and control strategies. Preventive Veterinary Medicine, Amsterdam, v. 109, n. 3-4, p. 228-235, 2013. DOI: 10.1016/j.prevetmed.2012.10.017

WALKER, R. S.; MILLER, J. E.; MONLEZUN, C. J.; LAMAY, D.; NAVARRE, C.; ENSLEY, D. Gastrointestinal nematode infection and performance of weaned stocker calves in response to anthelmintic control strategies. Veterinary Parasitology, Amsterdam, v. 197 , n. $1-2$, p. $152-159$, 2013. DOI: $10.1016 / \mathrm{j}$. vetpar.2013.07.011 
